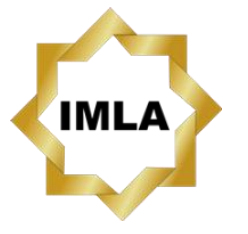

Available online:

http://journal.imla.or.id/index.php/arabi

Arabi : Journal of Arabic Studies, 2 (1), 2017, 47-53

DOI: http://dx.doi.org/10.24865/ajas.v2i1.25

\title{
PENGARUH BENTUK TES FORMATIF DAN SIKAP BELAJAR TERHADAP HASIL BELAJAR MEMBACA BAHASA ARAB
}

\author{
Muhammad Isnaini, Jehan Ananda Aliyah Kapitan Hitu \\ Pusat Pengembangan dan Pemberdayaan Pendidik \\ dan Tenaga Kependidikan (PPPPTK) Bidang Bahasa \\ E-mail : isnaini@gmail.com
}

\begin{abstract}
This research aims to investigate the effect of formative tests and students 'attitudes toward students' reading comprehension at Madrasah Aliyah Negeri (MAN) 13 Jakarta. The method employed in this research is true experiment. The results showed that: (1) the result of students' reading comprehension who were given the formative test in narrative form is higher than the group of students who were given the multiple choice of formative test, (2) there is an positive interaction between the formative test and the students' attitude toward the students' reading comprehension, (3) the average reading scores of students who have positive attitude toward Arabic subject is higher when they do the narrative form of formative test, (4) the average reading scores of students who were given the formative test in narrative form is lower than the students whom were given the multiple choice of formative test despite both group of students have negative attitude toward Arabic subject. The conclusion is that there is an impact of formative tests and students' attitudes toward students' reading comprehension.
\end{abstract}

Keywords: formative test, students' attitude, reading comprehension, Arabic language learning

\begin{abstract}
Abstrak
Penelitian ini bertujuan untuk meneliti pengaruh bentuk tes formatif dan sikap siswa terhadap hasil belajar membaca bahasa Arab siswa di MAN 13. Metode yang digunakan dalam penelitian ini adalah metode True Experiment. Hasil penelitian menunjukkan bahwa: (1) secara keseluruhan terbukti bahwa hasil belajar membaca bahasa Arab kelompok siswa yang diberi tes formatif bentuk uraian lebih tinggi daripada kelompok siswa yang diberi tes formatif bentuk pilihan ganda, (2) terdapat interaksi bentuk tes formatif dengan sikap siswa pada hasil belajar membaca bahasa Arab, (3) terbukti bahwa skor rata-rata hasil belajar membaca bahasa Arab kelompok siswa yang memiliki sikap positif yang diberi tes formatif bentuk uraian lebih tinggi daripada kelompok siswa yang memiliki sikap positif yang diberi tes formatif bentuk pilihan ganda, (4) terbukti bahwa skor rata-rata hasil belajar membaca bahasa Arab siswa yang memiliki sikap negatif yang diberi tes formatif bentuk uraian lebih rendah daripada kelompok siswa yang memiliki sikap negatif yang diberi tes formatif bentuk pilihan ganda. Berdasarkan hal tersebut dapat disimpulkan bahwa terbukti adanya pengaruh bentuk tes formatif dan sikap terhadap hasil belajar membaca bahasa Arab.
\end{abstract}

Kata Kunci: tes formatif, sikap siswa, hasil belajar membaca, pembelajaran bahasa Arab 


\section{Arabi : Journal of Arabic Studies}

\section{Pendahuluan}

Pada umumnya, pengetahuan dan pengalaman siswa dalam proses pembelajaran dipengaruhi oleh faktor eksternal dan internal yang saling berkaitan. Faktor eksternal yaitu suatu hal yang berasal dari luar diri siswa, seperti guru, situasi kelas, metode pendidikan, latar belakang ekonomi, latar belakang sosial dan sebagainya yang berpengaruh terhadap prestasi belajar siswa. Sedangkan faktor internal yaitu keadaan yang mempengaruhi keberhasilan siswa yang berasal dari dalam. Istilah ini menunjukkan adanya pembawaan yang dimiliki siswa, yang meliputi aspek psikologis, seperti kesehatan fisik, kesehatan psikis, minat, bakat dan sikapnya.

Hal-hal yang termasuk faktor internal merupakan hal penting yang mendorong keberhasilan siswa dalam mengembangkan kemampuan belajarnya, khususnya aspek sikap. Saat berlangsung proses belajar mengajar, sikap berperan sebagai alat pengendalian diri, misalnya dengan adanya sikap yang baik seseorang akan mampu menempatkan diri dengan situasi yang dihadapinya. Sikap merupakan kesiapan mental individu yang mempengaruhi, mewarnai, bahkan menentukan kegiatan individu yang bersangkutan dalam memberikan respon terhadap objek atau situasi yang dihadapinya.

Seorang siswa yang memiliki sikap positif pada materi pelajaran, dalam hal ini pelajaran bahasa Arab, maka ia akan berupaya secara maksimal untuk membiasakan belajar dengan baik. Bahkan sikap positif itu memungkinkan pula termanifestasi dalam bentuk pengalamannya, hal ini sejalan dengan pembelajaran bahasa Arab yang berupaya menanamkan sikap positif agar siswa memiliki pemahaman dan pengalaman yang baik ketika mempelajarinya.

Proses pembelajaran merupakan suatu proses yang mengandung serangkaian perbuatan guru dan siswa atas dasar hubungan timbal balik dalam situasi edukatif untuk mencapai tujuan pembelajaran (Albantani, 2015: 179). Alat untuk mengetahui apakah tujuan pembelajaran tercapai disebut evaluasi. Evaluasi yang baik haruslah didasarkan atas tujuan pembelajaran yang ditetapkan oleh guru dan benar-benar diusahakan pencapaiannya oleh guru dan siswa. Tujuan pembelajaran yang sudah ditetapkan harus diwujudkan dalam pembelajaran, materi dan evaluasi. Hal ini harus merupakan satu rantai yang tak terpisahkan. Selain itu, evaluasi mempunyai kegunaan bagi berbagai pihak yang mencakup kegunaan bagi siswa, kegunaan bagi guru, kegunaan bagi sekolah, kegunaan bagi orang tua siswa dan mempunyai kegunaan khusus untuk berbagai pihak.

Tujuan melakukan evaluasi dalam proses pembelajaran adalah untuk mendapatkan informasi yang akurat tentang pencapaian standar kompetensi siswa sehingga dapat diupayakan tindak lanjutnya. Salah satunya adalah dengan pemberian tes formatif. Tes formatif yang disajikan di tengah program pembelajaran bertujuan untuk memantau apakah program pembelajaran telah sesuai dengan keadaan siswa dan memonitor kemajuan belajar siswa. Ada beberapa bentuk tes formatif yaitu diantaranya tes objektif dan tes esai. Tes objektif itu sendiri banyak ragamnya yaitu bentuk pilihan ganda, benar-salah, atau menjodohkan. Bentuk tes pilihan ganda itu ada dua, yaitu bentuk tes pilihan ganda biasa dan tes pilihan ganda asosiasi. Berdasarkan pengamatan penulis di lapangan, tes yang paling banyak digunakan sekarang adalah pemberian tes formatif pilihan ganda. Dikaitkan dengan hasil belajar bahasa Arab yang makin merosot, guru perlu mengetahui bentuk tes formatif mana yang lebih efektif untuk diberikan kepada siswa.

Oleh karena itu, artikel ini hanya akan terfokus pada pengaruh bentuk tes formatif terhadap hasil belajar bahasa Arab, khususnya pembelajaran membaca dan mengamati keterkaitan antara bentuk tes formatif dengan sikap siswa terhadap pelajaran bahasa Arab. Dengan demikian diharapkan para pengajar bahasa Arab dapat menentukan bentuk tes formatif yang lebih efektif untuk meningkatkan hasil belajar membaca bahasa Arab para siswanya. Selain itu, para pengajar juga dapat mengetahui pengaruh sikap terhadap keberhasilan siswa untuk memahami bahasa Arab.

\section{Metode Penelitian}

Metode yang digunakan dalam penelitian ini adalah metode eksperimen. Dalam metode eksperimen dibentuk dua kelompok yang terdiri dari satu kelompok eksperimen dan satu kelompok 
kontrol. Kepada kelompok eksperimen diberikan perlakuan dengan pemberian tes formatif bentuk esai, dan pada kelompok kontrol diberikan perlakuan dengan pemberian tes formatif bentuk pilihan ganda.

Perlakuan yang diterapkan dalam penelitian ini adalah bentuk soal tes formatif yang diberikan dalam bentuk ulangan harian dan umpan baliknya. Kepada kelompok eksperimen diberikan perlakuan dengan bentuk soal tes formatif esai dan pada kelompok kontrol diberikan perlakuan dengan bentuk soal tes formatif pilihan ganda.

Populasi target dalam penelitian ini adalah semua siswa MAN 19 Jakarta. Sedangkan populasi terjangkau pada penelitian ini adalah siswa kelas X MAN 19 Jakarta. Berdasarkan populasi tersebut, maka untuk menetapkan sampel diambil dua kelas dengan teknik desain kelompok acak (random group design) melalui undian. Setelah diperoleh dua kelas yang terpilih sebagai sampel, selanjutnya melalui undian dipilih kelas yang akan diberi perlakuan bentuk soal tes formatif esai dan bentuk soal tes formatif pilihan ganda.

Langkah selanjutnya adalah memberikan kuesioner sikap siswa terhadap mata pelajaran bahasa Arab untuk mengelompokkan siswa dalam kelompok siswa yang memiliki sikap positif dan siswa yang memiliki sikap negatif terhadap mata pelajaran bahasa Arab. Hasil pengisian kuesioner sikap siswa terhadap mata pelajaran bahasa Arab kemudian diberi sekor, dan diurutkan dari sekor tertinggi hingga sekor terendah dari para siswa untuk masing-masing kelas.

Data dalam penelitian ini merujuk kepada tiga aspek yaitu hasil belajar bahasa Arab, bentuk soal tes formatif, dan sikap siswa terhadap pelajaran bahasa Arab. Sedangkan ada dua jenis data yang dikumpulkan yaitu hasil belajar bahasa Arab dan sikap siswa. Data hasil belajar bahasa Arab diperoleh dengan mengunakan instrumen yang dikembangkan sendiri oleh peneliti. Data sikap siswa diperoleh dengan menggunakan tes skala sikap yaitu skala Likert $(1,2,3,4,5)$. Data hasil kedua tes tersebut kemudian diolah dengan analisis deskriptif dan inferensial untuk menguji hipotesis penelitian.

Pengujian hipotesis penelitian ini dilakukan dengan menggunakan teknik analisis variansi (ANAVA) dua jalan sesuai rancangan faktorial $2 \times 2$ pada taraf signifikansi $\alpha=0,05$. sebelum menggunakan ANAVA terlebih dahulu dilakukan uji persyaratan analisis yang meliputi uji normalitas dan uji homogenitas variansi. Uji normalitas bertujuan untuk melihat kenormalan sampel dengan menggunakan uji Liliefors. ${ }^{1}$ Untuk mengetahui homogenitas varians dilakukan dengan menggunakan uji Bartlett. ${ }^{2}$

\section{Hasil Penelitian dan Pembahasan}

Pada dasarnya tujuan penelitian ini adalah untuk mendapatkan upaya pembaharuan dalam proses pembelajaran melalui pemberian bentuk tes formatif dilihat dari sikap siswa yang pada akhirnya dapat meningkatkan hasil belajar bahasa Arab siswa, yang mana hasilnya telah diungkapkan di atas. Berdasarkan hasil temuan tersebut maka akan dilakukan pembahasan terhadap hasil temuan tersebut.

\section{Perbedaan Hasil Belajar Bahasa Arab Siswa yang Diberikan Soal Tes Formatif Bentuk Uraian dengan Siswa yang Diberikan Soal Tes Formatif Bentuk Pilihan Ganda}

Berdasarkan hasil penelitian pada dua kelompok siswa dengan perlakuan bentuk tes formatif yang berbeda menunjukkan adanya perbedaan hasil belajar bahasa Arab antara kelompok siswa yang diberi tes formatif bentuk uraian dan kelompok siswa yang diberi tes formatif bentuk pilihan ganda. Perbedaan ini dapat dilihat dari perbedaan rerata skor hasil belajar bahasa Arab yang diperoleh setiap kelompok tersebut. Skor rata-rata hasil belajar bahasa Arab secara keseluruhan kelompok siswa yang diberi perlakuan tes formatif bentuk uraian, yaitu sebesar 84,4 lebih tinggi

\footnotetext{
${ }^{1}$ Sudjana, Metode Statistik (Bandung: Tarsito, 1996), pp. 466-467.

${ }^{2}$ Ibid., pp. 261-264.
} 


\section{Arabi : Journal of Arabic Studies}

dibandingkan dengan skor rata-rata hasil belajar bahasa Arab secara keseluruhan kelompok siswa yang diberi tes formatif bentuk pilihan ganda, yaitu 75,6.

Perbedaan tersebut selain ditunjukan oleh rerata skor juga ditunjukan oleh hasil perhitungan analisis varians. Hasil analisis varians untuk kedua bentuk tes formatif menunjukkan $\mathrm{F}_{\text {hitung }}$ sebesar 6,42. Sedangkan $F_{\text {tabel }}$ pada taraf signifikan $\alpha=0,05$ adalah sebesar 4,17 . Ini berarti $F_{\text {hitung }}$ lebih besar daripada $F_{\text {tabel. }}$. Hasil pengujian tersebut membuktikan bahwa terdapat perbedaan yang signifikan antara hasil antara hasil belajar bahasa Arab kelompok siswa yang diberi perlakuan tes formatif bentuk uraian dengan kelompok siswa yang diberi perlakuan tes formatif bentuk pilihan ganda.

Hasil penelitian ini menunjukkan bahwa secara keseluruhan hasil belajar bahasa Arab kelompok siswa yang diberi tes formatif bentuk uraian lebih tinggi daripada hasil belajar bahasa Arab yang diberi tes formatif pilihan ganda. Hal ini menunjukkan bahwa salah satu upaya untuk meningkatkan hasil belajar bahasa Arab dapat dilakukan dengan pemberian tes formatif bentuk uraian.

Pemberian tes formatif bentuk uraian lebih baik daripada pemberian tes formatif bentuk pilihan ganda. Dalam hal ini siswa yang diberi perlakuan tes formatif bentuk uraian akan lebih memahami dan terbiasa menuangkan ide dan gagasan serta akan lebih mudah menjawab semua pertanyaan dengan tepat dan jelas. Dengan kebiasaan atau latihan seperti hal tersebut maka untuk menjawab setiap pertanyaan selalu terfokus pada pertanyaan dan jawabannya pun selalu relevan.

\section{Interaksi antara Bentuk Soal Tes Formatif dan Sikap Siswa dengan Hasil Belajar Bahasa Arab}

Berdasarkan pada hasil penelitian, perbedaan hasil belajar bahasa Arab bukan merupakan pengaruh dari bentuk tes formatif dan sikap siswa. Dalam penelitian ini secara sangat dignifikan dapat diperlihatkan tidak adanya interaksi di antara kedua variabel tersebut. Berdasarkan hasil analisis varian diketahui bahwa $F_{\text {fitung }}$ sebesar 0,14 . Sedangkan $F_{\text {tabel }}$ pada taraf signifikan $\alpha=0,05$ sebesar 4,17 dan pada taraf signifikan $\alpha=0,01$ sebesar 67,56. Hasil ini menunjukkan bahwa tidak terdapat interaksi antara bentuk tes formatif dan sikap siswa dengan belajar bahasa Arab.

Hasil ini membuktikan bahwa tidak ada pengaruh yang berbeda terhadap hasil belajar bahasa Arab jika disampaikan pada kelompok siswa yang memiliki sikap yang berbeda.

\section{Perbedaan Hasil Belajar Bahasa Arab Siswa yang Memiliki Sikap Positif yang Diberikan Soal Tes Formatif Bentuk Uraian dengan Siswa yang Diberikan Soal Tes Formatif Bentuk Pilihan Ganda}

Pengujian pada hipotesis keempat ini menunjukkan bahwa skor rata-rata hasil belajar bahasa Arab secara keseluruhan kelompok siswa yang memiliki sikap positif yang diberi bentuk tes formatif uraian, yaitu sebesar 84,5 lebih tinggi daripada skor rata-rata hasil belajar bahasa Arab secara keseluruhan kelompok siswa yang diberi tes formatif bentuk pilihan ganda, yaitu sebesar 75,6 .

Hal ini membuktikan bahwa terdapat perbedaan yang sangat signifikan antara dua kelompok tersebut. Hal tersebut juga menunjukkan bahwa secara keseluruhan hasil belajar bahasa Arab kelompok siswa yang memiliki sikap positif yang diberi tes formatif bentuk uraian lebih tinggi daripada hasil belajar bahasa Arab kelompok siswa yang diberi tes formatif bentuk pilihan ganda.

\section{Perbedaan Hasil Belajar Bahasa Arab Siswa yang Memiliki Sikap Negatif yang Diberikan Soal Tes Formatif Bentuk Uraian dengan Siswa yang Diberikan Soal Tes Formatif Bentuk Pilihan Ganda}

Berdasarkan hasil analisis menunjukkan bahwa skor rata-rata hasil belajar bahasa Arab siswa yang memiliki sikap negatif yang diberi tes formatif bentuk pilihan ganda, yaitu 84,4 lebih tinggi daripada skor rata-rata siswa yang memiliki sikap negatif yang diberi tes formatif bentuk uraian, yaitu 72,7 . 
Sehingga dapat disimpulkan bahwa pemberian perlakuan untuk kedua bentuk tes formatif tidak mempunyai pengaruh yang signifikan pada kelompok siswa yang memiliki sikap negatif.

Berdasarkan uraian hasil penelitian di atas dapat disimpulkan bahwa pemberian perlakuan kedua bentuk tes formatif dan sikap mempunyai pengaruh yang signifikan terhadap hasil belajar bahasa Arab. Khususnya, pemberian perlakuan tes formatif bentuk uraian akan mempunyai pengaruh yang sangat signifikan jika diberikan kepada kelompok siswa yang memiliki sikap positif. Namun, pemberian perlakuan tes formatif ternyata tidak berpengaruh jika diberikan kepada kelompok siswa yang memiliki sikap negatif.

\section{Keterbatasan Penelitian}

Pelaksanaan penelitian ini diupayakan dan dikontrol agar hasilnya dapat diterima kebenarannya secara ilmiah sesuai dengan prosedur dan tujuan yang ingin dicapai. Untuk itu telah dilakukan dengan proses mulai dari penentuan populasi, penarikan sampel, penyusunan instrumen, uji coba instrumen sampai dengan pelaksanaan perlakuan terhadap masing-masing kelompok sampel. Namun upaya-upaya yang dilakukan tidak terlepas dari berbagai kekurangan dan kelemahan sebagai akibat keterbatasan penelitian yang ada. Keterbatasan penelitian tersebut merupakan faktor-faktor yang tidak dapat dihindarkan dan dikendalikan, terutama pada saat perlakuan, adapun keterbatasan dalam penelitian ini antara lain berikut ini.

1. Penelitian ini hanya dibatasi oleh variabel sikap dan bentuk tes formatif sehingga tidak menut up kemungkinan ada variabel lain yang ikut berpengaruh terhadap hasil penelitian ini.

2. Pokok bahasan yang disampaikan dibatasi hanya pada materi pelajaran bahasa Arab kelas $\mathrm{X}$ semester 1 .

3. Jumlah sampel yang kecil sehingga dimungkinkan dapat mempengaruhi keputusan yang diperoleh untuk membuat kesimpulan. Selain itu, penelitian ini hanya melibatkan siswa kelas $\mathrm{X}$ semester 1 di MAN 13 Jakarta. Responden penelitian ini sebanyak 2 kelompok masingmasing 20 siswa. Dengan demikian, generalisasi temuan penelitian hanya berlaku secara terbatas.

4. Pelaksanaan penelitian ini tidak dilakukan secara terpisah, tetapi mengikuti kelas dan mata pelajaran reguler. Ini berarti siswa yang menjadi subyek penelitian bergabung dengan siswa yang bukan subyek penelitian dan bersama-sama menerima perlakuan eksperimen. Di dalam proses pembelajaran tentu terjadi interaksi di antara mereka, sehingga hal ini kemungkinan akan mempengaruhi hasil penelitian.

\section{Simpulan}

Simpulan yang dapat disajikan dalam penelitian ini adalah sebagai berikut ini.

1. Secara keseluruhan terbukti bahwa hasil belajar bahasa Arab kelompok siswa yang diberi tes formatif bentuk uraian lebih tinggi daripada kelompok siswa yang diberi tes formatif bentuk pilihan ganda.

2. Terdapat interaksi bentuk tes formatif dengan sikap siswa pada hasil belajar membaca bahasa Arab.

3. Terbukti bahwa skor rata-rata hasil belajar membaca bahasa Arab kelompok siswa yang memiliki sikap positif yang diberi tes formatif bentuk uraian lebih tinggi daripada kelompok siswa yang memiliki sikap positif yang diberi tes formatif bentuk pilihan ganda.

4. Terbukti bahwa skor rata-rata hasil belajar membaca bahasa Arab siswa yang memiliki sikap negatif yang diberi tes formatif bentuk uraian lebih rendah daripada kelompok siswa yang memiliki sikap negatif yang diberi tes formatif bentuk pilihan ganda.

Berdasarkan hal tersebut secara umum dapat disimpulkan bahwa terbukti adanya pengaruh bentuk tes formatif dan sikap terhadap hasil belajar bahasa Arab. 


\section{Arabi : Journal of Arabic Studies}

Secara umum hasil penelitian ini dapat memberikan masukan kepada guru bahasa Arab di Madrasah Aliyah sebagai bahan pertimbangan dalam memberikan tes formatif yang sesuai dengan sikap siswa, terutama sikap positif dan negatif. Implikasi dalam penelitian ini adalah berikut ini.

1. Untuk meningkatkan hasil belajar membaca bahasa Arab sebaiknya guru bahasa Arab Madrasah Aliyah menggunakan tes formatif bentuk uraian.

2. Pemberian tes formatif bentuk uraian dan tes formatif bentuk pilihan ganda pada kelompok siswa yang memiliki sikap positif menunjukkan adanya perbedaan yang sangat signifikan. Sehingga pada kelompok siswa ini guru dapat memberikan tes formatif bentuk uraian.

3. Pemberian tes formatif bentuk uraian dan tes formatif bentuk pilihan ganda pada kelompok siswa yang memiliki sikap negatif menunjukkan adanya perbedaan yang tidak signifikan. Sehingga pada kelompok siswa ini guru dapat memberikan tes formatif bentuk pilhan ganda. Pemberian tes formatif yang sesuai akan dapat meningkatkan hasil belajar bahasa Arab. Dengan kata lain, untuk meningkatkan hasil belajar membaca bahasa Arab di antaranya tergantung pula pada bentuk tes formatif yang diberikan dan sikap siswa selain komponen atau variabelvariabel lain yang turut mempengaruhi hasil belajar bahasa Arab.

Penemuan ini dapat dijadikan pertimbangan dalam pengembangan materi pembelajaran, tujuan pembelajaran, dan proses pembelajaran dalam pencapaian hasil belajar. Berdasarkan simpulan dan implikasi penelitian yang dipaparkan di atas, maka dapat disampaikan saran-saran berikut ini.

1. Untuk meningkatkan hasil belajar membaca bahasa Arab sebaiknya guru mata pelajaran bahasa Arab di Madrasah Aliyah menggunakan bentuk tes formatif yang sesuai.

2. Secara umum pemberian tes formatif bentuk uraian lebih baik daripada pemberian tes formatif bentuk pilihan ganda. Oleh karena itu, guru hendaknya menggunakan tes formatif bentuk uraian untuk meningkatkan hasil belajar membaca bahasa Arab.

3. Bentuk tes formatif dan sikap merupakan salah satu komponen yang dapat mempengaruhi hasil belajar bahasa Arab. Oleh karena itu, guru hendaknya memperhatikan sikap siswa dalam memberikan tes formatif sehingga guru dapat menetapkan pilihan bentuk tes formatif yang sesuai dengan sikap siswa atau hendaknya guru menggunakan bentuk tes yang bervariasi dalam memberikan tes formatif.

Untuk memperoleh hasil yang lebih baik, seyogyanya ada penelitian lebih lanjut dengan melibatkan variabel lain yang mempengaruhi hasil belajar bahasa Arab seperti motivasi, minat, intelegensi, dan komponen-komponen lain yang turut mempengaruhi hasil belajar bahasa Arab. Selain itu, kiranya perlu diperhatikan ruang lingkup permasalahan yang lebih luas yang dapat melibatkan populasi dan sampel yang lebih banyak.[]

\section{Daftar Rujukan}

Albantani, Azkia Muharom. 2015. "Implementasi Kurikulum 2013 pada Pembelajaran Bahasa Arab di Madrasah Ibtidaiyah" Arabiyat : Jurnal Pendidikan Bahasa Arab dan Kebahasaaraban, Vol. 2 No. 2.

Azwar, Saifudin. 1996. Tes Prestasi: Fungsi dan pengembangan Pengukuran Prestasi Belajar, Yogyakarta: Pustaka Pelajar.

Nitko, Anthony J. 1996. Educational Assessment of Students .New Jersey: Prentice- Hall, Inc.

Popham, James W. 1981. Modern Educational Measurement. Englewood Clift: Prentice -Hall.

Pudjiastuti, Sri. 2002. Pengaruh Bentuk Tes Formatif dan Sikap pada Pelajaran Matematika terhadap Hasil Belajar Matematika. Jakarta: UNJ.

Purwanto, M. Ngalim. 1998. Ilmu Pendidikan Teoretis dan Praktis. Bandung: Remaja Rosdakarya.

Pusat Kurikulum. 2003. Standar Kompetensi Mata Pelajaran Bahasa Arab SMA dan MA. Jakarta: Balitbang Depdiknas.

Vol. 2 No. 1 | $52-53$

Copyright @ 2017 | ARABI | p-ISSN 2548-6616 | e-ISSN 2548-6624 
Arabi : Journal of Arabic Studies

Rakhmat, Jalaluddin. 1999. Psikologi Komunikasi. Bandung: Remaja Rosdakarya.

Safi'ie, Imam. 1996. Pedoman Pembelajaran Bahasa Indonesia, Jakarta: Depdikbud.

Slameto. 1988. Evaluasi Pendidikan. Jakarta: Bina Aksara.

Soenardi, M. Djiwandono. 1996. Tes Bahasa dalam Pengajaran . Bandung: ITB.

Sudiyono, Anas. 1998. Pengantar Evaluasi Pendidikan . Jakarta: Raja Grafindo Persada.

Sudjana, Nana. 1995. Penilaian Hasil Proses Belajar Mengajar. Bandung: Remaja Rosdakarya.

Undang-undang No. 20 tahun 2003 tentang Sistem Pendidikan Nasional. 